\section{Australian Journal of \\ Crop Science}

AJCS 15(03):409-415 (2021)

doi: 10.21475/ajcs.21.15.03.p2904
ISSN:1835-2707

\title{
Decomposed babassu biomass residue enhances the initial development of cassava (Manihot esculenta Crantz)
}

\author{
Hosana Aguiar Freitas de Andrade ${ }^{1}$, Raissa Rachel Salustriano da Silva-Matos ${ }^{2}$, Nitalo André Farias \\ Machado ${ }^{*^{1,2}}$, Analya Roberta Fernandes Oliveira ${ }^{1}$, Valdryckson Costa Garreto ${ }^{2}$, Marcos Renan Lima Leite ${ }^{3}$, \\ Samuel Ferreira Pontes ${ }^{3}$, Alineaurea Florentino Silva ${ }^{4}$, Francisca Gislene Albano-Machado ${ }^{1}$, Paulo Roberto \\ Coelho Lopes ${ }^{4}$
}

\author{
${ }^{1}$ Center of Agrarian Sciences, Federal University of Ceará (UFC), Fortaleza, Brazil \\ ${ }^{2}$ Center of Agrarian Sciences and Environmental, Federal University of Maranhão (UFMA), Chapadinha, Brazil \\ ${ }^{3}$ Center of Agrarian Sciences, Federal University of Piauí (UFPI), Teresina, Brazil \\ ${ }^{4}$ Empresa Brasileira de Pesquisa Agropecuária, Embrapa Semiárido, Petrolina, Brazil
}

*Corresponding author: nitalo-farias@hotmail.com

\begin{abstract}
Cassava is a tuber of significant cultural and economic importance for family farming. However, cultivation in the northeastern region of Brazil is characterized by low productivity, resulting from cultivation in naturally marginal soil, which can cause food insecurity to farmers in the region. The objective was to evaluate the initial development of cassava using substrates derived from decomposed residue from babassu biomass, as a supplement to the soils with low natural fertility. The experiment was carried out in a greenhouse in the municipality of Chapadinha, state of Maranhão, Brazil. The treatments consisted of six inclusion levels of babassu biomass (BB) in the substrates: $S_{0}, 100 \%$ soil; $S_{20}, 20 \%$ BB $+80 \%$ soil; $S_{40}, 40 \%$ BB $+60 \%$ soil; $S_{60}, 60 \%$ $\mathrm{BB}+40 \%$ soil; $\mathrm{S}_{80}, 80 \% \mathrm{BB}+20 \%$ soil; and $\mathrm{S}_{100}, 100 \% \mathrm{BB}$. The treatments were arranged in a completely randomized design, with four replications. The soil used in the experiment is classified as dystrophic Yellow Oxisol. At the end of the experiment, the following were evaluated: percentage of cuttings survival, leaf area, shoot length, shoot diameter, root length, root volume, aerial part dry mass and root dry mass. With the exception of the sprout diameter, the inclusion of BB in the substrates provided a significant positive effect for all analyzed variables, which demonstrates the early response capacity of cassava seedlings to the use of organic waste associated with the soil low fertility. The use of babassu biomass as an organic fertilizer improves soil fertility, stimulating the growth and development of cassava seedlings in a sustainable production system.
\end{abstract}

Keywords: Attalea speciosa M., Changes quality., Manihot esculenta C., Organic substrate.

Abbreviations: BB_babassu biomass; S_cutting survival; LA_leaf area; $S L_{-}$sprout length; $\mathrm{SD}_{\text {_ }}$ sprout diamenter; RL_root length; RV_root volume; APDM_aerial part dry mass; RDM_root dry mass.

Introduction

Cassava (Manihot esculenta Crantz) is a tuber of significant cultural and economic importance, representing a raw material with great potential for industrial use due to the variety of products obtained from its roots (Costa et al., 2017). In this regard, cassava deserves attention for contributing towards food security and generating employment/income for family farmers in the tropics and subtropics (Turyagyenda et al., 2013).

In Brazil, small farmers in the northeastern region have the second largest cassava cultivation area in the country (approximately 34\%). However, compared to that of the southern region (21.71 $\left.\mathrm{t} \mathrm{ha}{ }^{-1}\right)$, which has a higher productivity (IBGE, 2019), the average yield in the northeast is low $\left(9.81 \mathrm{t} \mathrm{ha}^{-1}\right)$. Essentially, a low productivity is the result of not adopting suitable agronomic practices (Gnahoua et al., 2016) and cultivation in marginal soils (Okogbenin et al., 2013).
Cultivation on naturally poor soils relies heavily on fertilizers to maintain satisfactory nutrient levels. However, farmers do not fertilize soils for cassava cultivation due to a lack of financial resources and high production rates without adequate fertilization (Omar et al., 2012). Consequently, with continuous extraction from the soil causing an exponential reduction in nutrients (Namoi et al. 2014), food insecurity is possible for the families who depend upon this crop.

Furthermore, the growing demand from the food industry for new sources of starch has culminated in the cultivation of more competitive cassava cultivars (Fernandez et al., 2016). Therefore, it is essential that family farmers employ techniques that improve profitability, such as the use of regional organic fertilizers, which increases production and reduces costs compared to conventional fertilization.

In our study region, and across a large part of the eastern Amazon, the decomposed residue from the babassu palm 
(Attalea speciosa Mart.) could be used to increase the fertility of marginal soils. The babassu palm, a dominant plant species in degraded lands, is capable of growing in poor soils. Farming babassu palm requires the integration of traditional agroforestry with itinerant cultivation (Sousa; Moares and Gehring, 2016), which provides two main benefits: ruderal characteristics and socioeconomic value (Teixeira and Carvalho, 2007; Gehring et al., 2011).

Upon completion of the life cycle, babassu palms fall, after which the decomposition process begins. The residue from the decomposition process was collected and used empirically to supplement natural low fertility soils during the seedling production process. The hypothesis of this study was based on the assumption that the use of decomposed babassu residue would enhance the initial development of cassava. Therefore, the objective of this study was to evaluate the initial development of cassava using substrates composed of decomposed babassu residue.

\section{Results and Discussion}

With the exception of the sprout diameter (SD), the inclusion of babassu biomass (BB) in the substrate provided a significant positive effect for all analyzed variables. This result demonstrates the early response capacity of cassava seedlings to the use of organic waste associated with low soil fertility (Table 1 ).

\section{Analysis of the survival rate of cassava seedlings}

Cassava seedlings cultivated in a substrate with $60 \%$ BB $\left(\mathrm{S}_{60}\right)$ had a survival rate $(79.15 \%)$ that was $42.09 \%$ higher than that of the control $\left(S_{0}\right)(45.83 \%$; Figure 1). According to Rodrigues et al. (2008), the survival of cassava cuttings in the field normally corresponds to $55.4 \%$. Therefore, seedlings cultivated in $\mathrm{S}_{60}$ showed above average survival values.

Stake survival is an important parameter that determines whether stakes can be transplanted into the field based on their health. Thus, the greater the number of live cuttings, the better the material used during the propagation of cuttings. This highlights the importance of babassu biomass as a substrate due to the high rate of plant material multiplication.

\section{Biometric analysis of cassava seedlings}

The leaf area (LA) of the cassava seedlings showed a linear response. Expansion increased with the increase in the concentration of $B B$ in the soil, reaching $85.06 \mathrm{~cm}^{2}$ in the substrate consisting entirely of $B B\left(\mathrm{~S}_{100}\right)$ (Figure 2A). Fernández et al. (2016) observed a close relationship between the LA and amount of $N$, which explains why the addition of BB to the soil was accompanied by an increase in the available $\mathrm{N}$ content (by up to $89 \%$; Table 1 ) and promoted an increase in the LA.

Nitrogen is a constituent of chlorophyll, a vital molecule in the photosynthetic process (Taiz et al., 2014). Therefore, plants require $\mathrm{N}$ to maintain a satisfactory photosynthetic rate and produce photoassimilates, which are responsible for crop growth (Kanai et al., 2008).

When nitrogen deficiency occurs, that is, when the $\mathrm{N}$ content in the plant is below optimum, cassava plants may not express their productive potential. As shown by Cruz et al. (2006), significant reductions in the formation and leaf expansion rates of cassava plants can occur under nitrogendeficient conditions.
Nitrogen fertilizer, although indispensable for leaf development, is an expensive product for family farmers (Sangakkara and Wijesinghe, 2014). Therefore, the addition of this nutrient to the soil, such as through $\mathrm{BB}$, could reduce production-related costs and supplement fertilization.

The shoot length $(\mathrm{SL})$ was adjusted using a linear model. The $S L$ increased proportionally with the increase in the BB in the soil (Figure 2B). Cassava seedlings grown using a substrate with $100 \%$ BB obtained an average SL of $9.60 \mathrm{~cm}$. This was significantly higher (51.56\%) than that of shoots grown in soil without supplementation $\left(\mathrm{S}_{0}\right)$, which only grew to 4.65 $\mathrm{cm}$. This demonstrates the early response capacity of cassava seedling growth to the addition of organic fertilization.

The increased height of seedlings grown with BB may be a response to the nutrients provided by this residue to the soil, especially calcium, which promotes an increased growth in height when at an adequate content in the soil (Sousa et al., 2015). It was observed that the $S_{0}$ treatment contained only 0.80 cmolc $\mathrm{kg}^{-1}$ of calcium, which was $96.11 \%$ lower than that of $S_{100}$ at $20.60 \mathrm{cmolc} \mathrm{kg}^{-1}$ (Table 2). An increased SL would provide cassava with a competitive advantage against weed plant species when transplanting to field conditions (Pereira et al., 2012).

As shown in Figure $3 \mathrm{~A}, \mathrm{BB}$ supplementation had a linear effect on the root length (RL) of cassava seedlings. This was characterized by a $25.03 \mathrm{~cm}$ increase in the RL of seedlings produced on substrates composed of $100 \% \mathrm{BB}$, whereas seedlings grown using the control soil $\left(\mathrm{S}_{0}\right)$ only reached $15.97 \mathrm{~cm}$. Evidently, the increase in the growth of cassava seedlings accompanied the increase in organic fertilizer, possibly due to the increased soil porosity. The porosity of $\mathrm{S}_{0}$ was $45.99 \%$, while that of $S_{100}$ was $65.95 \%$ (Table 3 ). This implies that plants in the $S_{100}$ treatment had a greater area of root exploration, which increased the growth potential of the root system.

As shown in Figure 3B, the same response was obtained for the root volume (RV), which was adjusted using a quadratic equation. The substrate composed of $100 \%$ BB was responsible for promoting the greatest root volume (1.94 $\mathrm{cm}^{3}$ ). Such a response could also stem from the better root exploration capacity provided by $\mathrm{BB}$, as previously mentioned, providing the cassava seedlings with an increased RV of up to $47.9 \%$.

In addition, the substrate density is of great importance concerning the seedling quality. The substrate density can interfere with the root development, since high density values can promote greater mechanical impedance (Kratz et al., 2015). The inclusion of BB reduced the overall and particle densities to 0.33 and $0.97 \mathrm{~g} \mathrm{~cm}^{-3}$ (Table 3), respectively.

The findings of Alves (2002) highlight that the growth of cassava roots, up to 30 days after planting, depends upon the reserves (nutrients) present in the stem cuttings, which differs from our results. This proves that the substrate used during the planting of cassava cuttings can stimulate not only growth, but also root volume.

\section{Analysis of the biomass of cassava seedlings}

The aerial part dry mass (Figure $4 A$ ) and root dry mass (Figure $4 B$ ) of cassava seedlings were significantly influenced by the increase in BB in the substrate. The aerial and root biomass of cassava seedlings grown in a substrate composed of $100 \%$ BB increased by up to 59.3 and $62.5 \%$, respectively. 
Table 1. $P$ value and significance for the variables percentage of stake survival (S), leaf area (LA), shoot length (SL), shoot diameter $(S D)$, root length (RL), root volume (RV), aerial part dry mass (APDM) and root dry mass (RDM) of cassava cuttings as a function of the substrates based on babassu biomass.

\begin{tabular}{|c|c|c|c|c|}
\hline SV & $\mathrm{S} \%$ & LA & $S L$ & SD \\
\hline value - $p$ & $<0.0001^{* *}$ & $0.04 *$ & $<0.0001^{* *}$ & $0.14 \mathrm{~ns}$ \\
\hline $\mathrm{BB}$ & 806.64 & 961.94 & 15.43 & 0.23 \\
\hline $\mathrm{BB}$ & 48.88 & 515.19 & 0.95 & 0.12 \\
\hline CV (\%) & 11.74 & 35.81 & 12.94 & 19.26 \\
\hline SV & $R L$ & RV & APDM & RDM \\
\hline value - $p$ & $0.03^{*}$ & $0.0007^{* *}$ & $0.02 *$ & $0.08^{*}$ \\
\hline $\mathrm{BB}$ & 40.85 & 0.53 & 0.09 & 0.10 \\
\hline Resíduo & 13.33 & 0.07 & 0.03 & 0.04 \\
\hline CV (\%) & 18.07 & 18.77 & 22.27 & 21.19 \\
\hline
\end{tabular}

Table 2. $\mathrm{pH}$ values, electrical conductivity $(\mathrm{EC})$, organic matter $(\mathrm{OM})$, nitrogen $(\mathrm{N})$, phosphorus $(\mathrm{P})$, potassium (K), calcium (Ca) and magnesium $(\mathrm{Mg})$ of the substrates composed of babassu biomass.

\begin{tabular}{|c|c|c|c|c|c|c|c|c|}
\hline Substrates & $\mathrm{pH}$ & $\begin{array}{l}\mathrm{EC} \\
\mathrm{dS} \mathrm{m}^{-1}\end{array}$ & $\begin{array}{l}\text { OM } \\
\mathrm{g} \mathrm{kg}^{-1}\end{array}$ & $N$ & $\begin{array}{l}\mathrm{P} \\
\mathrm{mg} \mathrm{kg}^{-1}\end{array}$ & $\begin{array}{l}\mathrm{K} \\
\mathrm{cmol}_{\mathrm{c}} \mathrm{kg}^{-1}\end{array}$ & $\mathrm{Ca}$ & $\mathrm{Mg}$ \\
\hline $\mathrm{S}_{0}$ & 5.06 & 0.10 & 15.41 & 0.63 & 13 & 0.07 & 0.80 & 0.30 \\
\hline $\mathrm{S}_{20}$ & 4.88 & 0.61 & 25.45 & 1.23 & 14 & 0.67 & 1.60 & 1.00 \\
\hline$S_{40}$ & 5.11 & 1.36 & 37.03 & 1.46 & 13 & 1.82 & 3.20 & 1.70 \\
\hline$S_{60}$ & 4.83 & 1.79 & 70.55 & 2.02 & 13 & 2.35 & 4.40 & 2.80 \\
\hline $\mathrm{S}_{80}$ & 5.16 & 3.00 & 75.92 & 3.47 & 27 & 6.17 & 10.90 & 4.60 \\
\hline$S_{100}$ & 5.32 & 4.34 & 250.32 & 5.88 & 33 & 3.63 & 20.60 & 15.20 \\
\hline
\end{tabular}

$\mathrm{S}_{0}$ : $100 \%$ soil; $\mathrm{S}_{20}: 20 \%$ de BB $+80 \%$ de soil; $\mathrm{S}_{40}: 40 \%$ de BB $+60 \%$ de soil; $\mathrm{S}_{60}: 60 \%$ de BB $+40 \%$ de soil; $\mathrm{S}_{80}: 80 \%$ de $\mathrm{BB}+20 \%$ de soil; $\mathrm{S}_{100}: 100 \%$ de $B \mathrm{BB}$

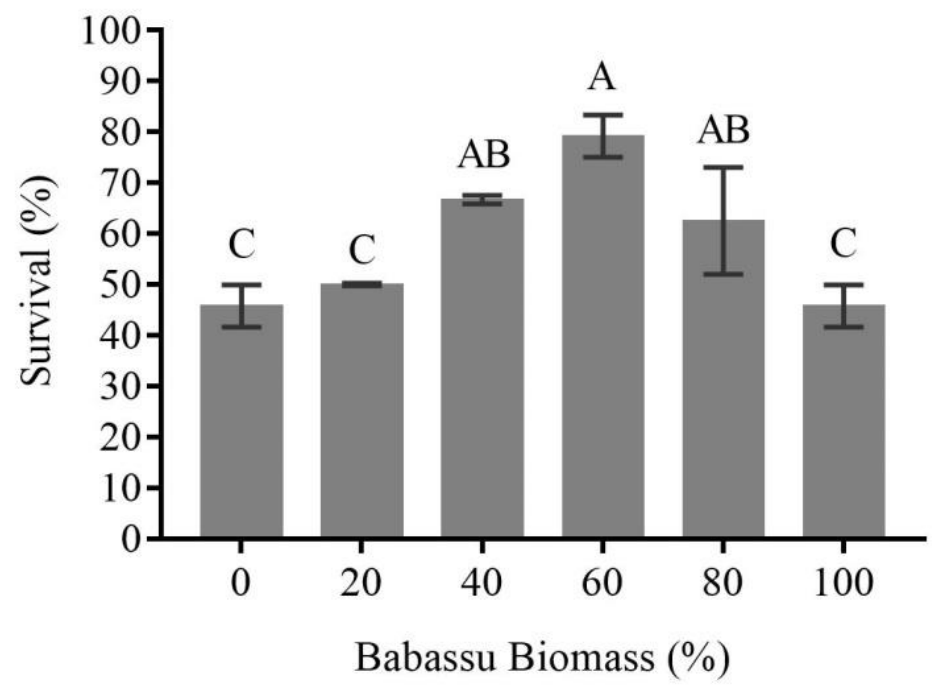

Fig 2. Survival of cassava cuttings as a function of babassu biomass doses in the composition of the substrates. The survival values of the cuttings were compared using the Tukey test $(p<0.05)$.

Table 3. Global density (DG), particle density (DP) and porosity (P) of the substrates composed of babassu biomass.

\begin{tabular}{llll}
\hline Substrates & Density $\left(\mathrm{g} \mathrm{cm}^{-3}\right)$ & Porosity (\%) \\
\hline $\mathrm{S}_{0}$ & $\mathrm{GD}$ & $\mathrm{PD}$ & 45.99 \\
$\mathrm{~S}_{20}$ & 1.44 & 2.67 & 51.53 \\
$\mathrm{~S}_{40}$ & 1.28 & 2.64 & 54.01 \\
$\mathrm{~S}_{60}$ & 1.18 & 2.57 & 56.22 \\
$\mathrm{~S}_{80}$ & 0.98 & 2.24 & 60.91 \\
$\mathrm{~S}_{100}$ & 0.73 & 1.88 & 65.95 \\
\hline $\mathrm{S}_{0}: 100 \%$ soil; $\mathrm{S}_{20}: 20 \%$ de BB $+80 \%$ de soil; $\mathrm{S}_{40}: 40 \%$ de BB $+60 \%$ de soil; $\mathrm{S}_{60}: 60 \%$ de BB $+40 \%$ de soil; $\mathrm{S}_{80}: 80 \%$ de BB $+20 \%$ de soil; $\mathrm{S}_{100}: 100 \%$ de BB.
\end{tabular}



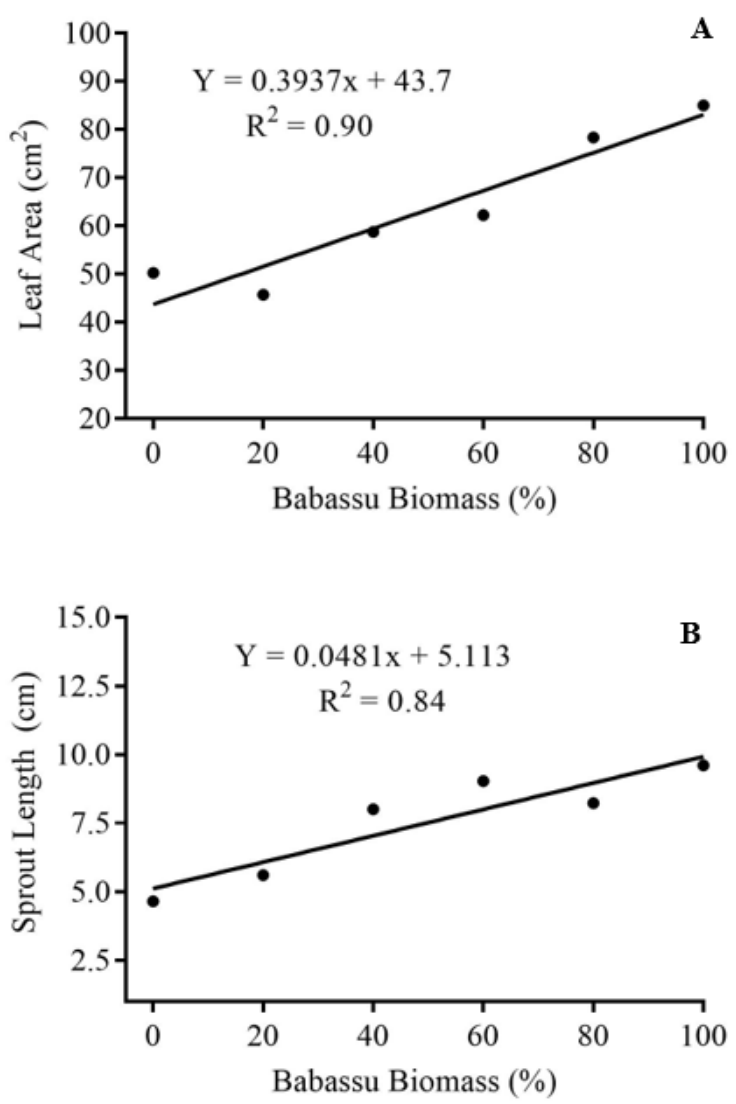

Fig 3. Leaf area (A) and shoot length (B) of cassava seedlings as a function of babassu biomass doses in the composition of the substrates.
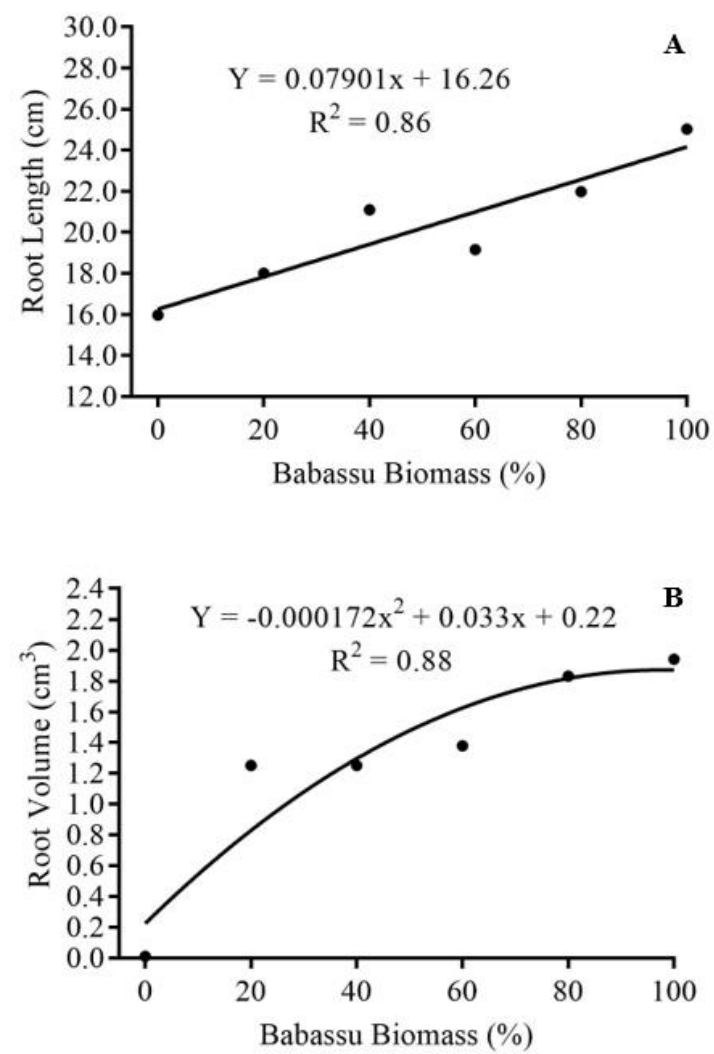

Fig 4. Root length (A) and root volume (B) of cassava seedlings as a function of babassu biomass doses in the composition of the substrates. 

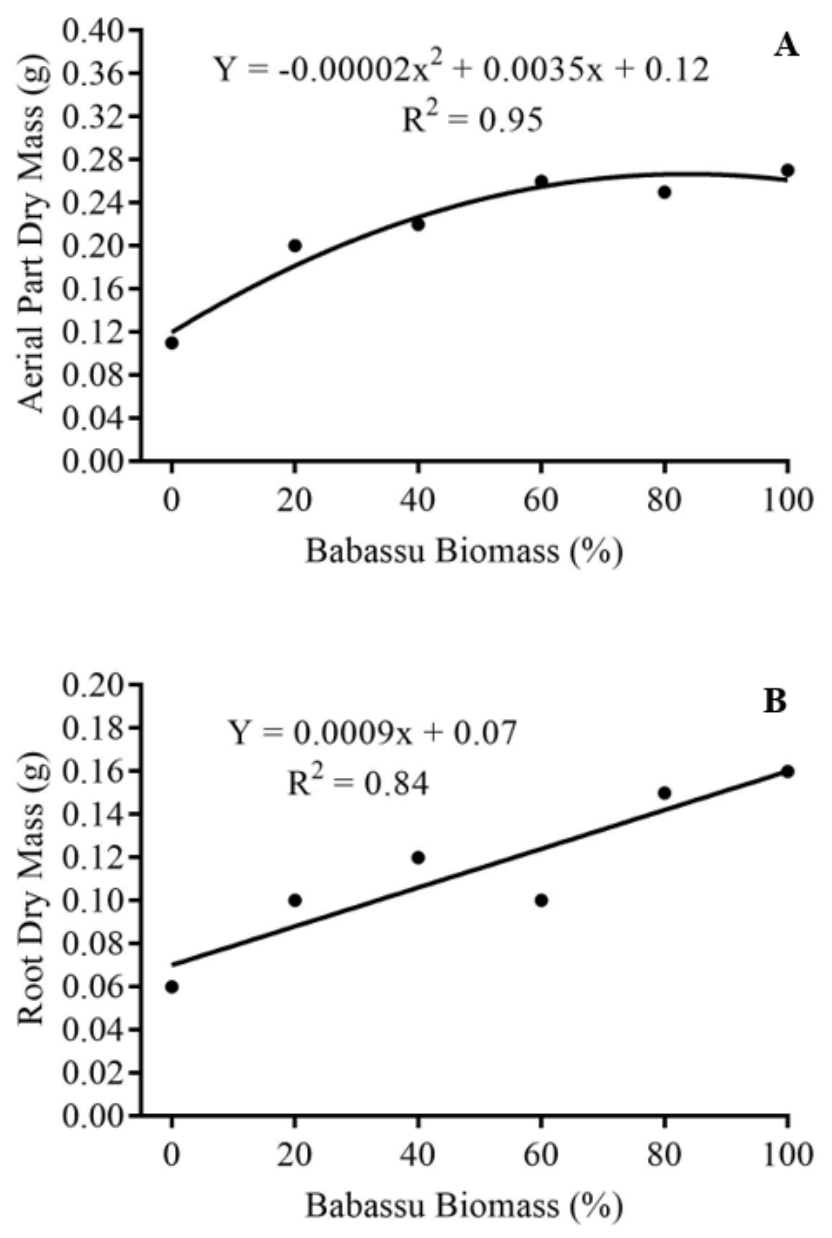

Fig 5. Dry mass of the aerial part (A) and root dry mass (B) of the cassava seedlings as a function of the babassu biomass doses in the composition of the substrates.

Babassu biomass, as an organic fertilizer, can also influence the availability of nutrients, and consequently increases their susceptibility to absorption by cassava seedlings. This contributes to the production of adequate biomass, which will eventually result in a greater tuber yield when transplanting to the field (Amanullah et al., 2007).

An increase in the availability of $P$ and $K$ accompanied the increase in $\mathrm{BB}$. In the $\mathrm{S}_{0}$ treatment, the available $\mathrm{K}$ and $\mathrm{P}$ were low, at only $0.07 \mathrm{cmolc} \mathrm{kg}^{-1}$ and $13 \mathrm{mg} \mathrm{kg}^{-1}$, respectively. However, BB provided $3.63 \mathrm{cmolc} \mathrm{kg}^{-1}$ and 33 $\mathrm{mg} \mathrm{kg}^{-1}$ of $\mathrm{K}$ and $\mathrm{P}$, respectively (Table 2 ).

Such macronutrients are indispensable for the growth and production of cassava throughout the crop cycle, as described by previous studies (Silva and Freire, 1968; Munyahali, et al., 2017; Biratu et al., 2018; Macalou et al., 2018; Muojiama et al., 2018). The data obtained in this study show that such importance arises during the initial stage of growth.

Although $\mathrm{K}$ and $\mathrm{P}$ are essential for cassava growth, $\mathrm{P}$ is the most limiting element in tropical soil conditions. While $\mathrm{K}$ can be replenished by mineral fertilizers, the availability of $P$ depends upon more than fertilizer addition. In acidic soils, $\mathrm{P}$ is poorly mobile and soluble, which is relevant in tropical soils as they have a low pH (Wortmann et al., 2019). In addition, the low natural levels and high immobilization capacity of this element are related to its occlusion in iron and aluminum oxides (Fageria et al., 2016), making it unavailable to plants.

Therefore, the development of this new agricultural strategy is an indispensable technological breakthrough that improves the physical and chemical quality of the soil, culminating in an increase in the production of cassava seedlings.

\section{Materials and Methods}

\section{Plant materials}

The cassava cuttings used in the trial were collected from the median portion of healthy parent plants that were obtained from local farmers. The piles were standardized at $0.12 \mathrm{~m}$ long with two nodes.

\section{Location and climate}

Between February and March 2018, the experiment was carried out in a greenhouse ( $75 \%$ luminosity) at the Center for Agricultural and Environmental Sciences of the Federal University of Maranhão (UFMA) (034'17 "S, 4320 '29 "W, altitude of $107 \mathrm{~m}$ ), located in Chapadinha, state of 
Maranhão, northeast region of Brazil. The region's climate is classified as humid tropical (Selbach and Leite, 2008), with the total annual rainfall ranging from 1.600 to 2.000 $\mathrm{mm}$ (Nogueira et al., 2012) and an average annual temperature of above $27^{\circ} \mathrm{C}$ (Passos et al., 2016).

\section{Design and conduct of the experiment}

The treatments consisted of six inclusion levels of babassu biomass (BB) in the substrates: $\mathrm{S}_{0}, 100 \%$ soil; $\mathrm{S}_{20}, 20 \% \mathrm{BB}+$ $80 \%$ soil; $\mathrm{S}_{40}, 40 \% \mathrm{BB}+60 \%$ soil; $\mathrm{S}_{60}, 60 \% \mathrm{BB}+40 \%$ soil; $\mathrm{S}_{80}$, $80 \% \mathrm{BB}+20 \%$ soil; and $\mathrm{S}_{100}, 100 \% \mathrm{BB}$. The treatments were arranged in a completely randomized design, with four replications. Each experimental unit consisted of six cassava cuttings.

The soil used in the experiment was classified as a dystrophic yellow oxisol with a sandy loam texture (Santos et al., 2013), characterized by a low natural fertility. The soil was collected from the upper layer $(0.00$ to $0.20 \mathrm{~m}$ deep) of soil at the UFMA experimental area. As proposed by Almeida et al. (2012), a sub-sample of the soil was collected for granulometric analysis, which revealed the following: $384 \mathrm{~g} \mathrm{~kg}^{-1}$ of coarse sand, $336 \mathrm{~g} \mathrm{~kg}^{-1}$ of fine sand, $112 \mathrm{~g} \mathrm{~kg}^{-1}$ of silt, $168 \mathrm{~g} \mathrm{~kg}^{-1}$ of total clay, and $38 \mathrm{~g} \mathrm{~kg}^{-1}$ of natural clay. The flocculation degree of the sample was 77 $\mathrm{g} 100 \mathrm{~g}^{-1}$.

The $\mathrm{BB}$ residue was collected from babassu palm stems undergoing decomposition in the village of Mangabeira, municipality of Chapadinha, state of Maranhão.

After collection, the babassu soil and biomass were sieved using a $4 \mathrm{~mm}$ diameter mesh and homogenized. Then, the substrates were composed according to each treatment formulation (v:v). Two sub-samples of each treatment were collected: one for chemical characterization (Table 2) and another for physical characterization (Table 3). The chemical characterization was carried out in accordance with Normative Instruction No. 17 of the Ministry of Agriculture, Livestock, and Supply of Brazil (BRASIL, 2007). The hydrogenionic potential was determined by direct measurement in solution of the substrate with water in the proportion 1: 2.5. The electrical conductivity was determined by direct reading with an electrode using a conductivity meter after obtaining the soil solution by the method of paste saturation with vacuum extraction.

The exchangeable calcium and magnesium contents were determined by atomic absorption spectrometry after extraction with $\mathrm{KCl} 1 \mathrm{~mol} \mathrm{~L}{ }^{-1}$. The contents of potassium and sodium were determined using a flame photometer, and the content of phosphor was obtained with a photocolorimeter after extraction with Melich 1 solution $\left(\mathrm{HCL} 0.05 \mathrm{~mol} \mathrm{~L}^{-1}+\mathrm{H}_{2} \mathrm{SO}_{4} 0.0125 \mathrm{~mol} \mathrm{~L}^{-1}\right)$.

The organic matter content was determined after extraction with $\mathrm{K}_{2} \mathrm{Cr}_{2} \mathrm{O}_{7} 0.2 \mathrm{~mol} \mathrm{~L}^{-1}$, followed by wet Walkley-Black digestion and titration with $\mathrm{FeH}_{20} \mathrm{~N}_{2} \mathrm{O}_{14} \mathrm{~S}_{2}$ solution at 0.05 $\mathrm{mol} \mathrm{L}^{-1}$. The nitrogen content was determined using a method adapted from Kjeldahl, with digestion in $\mathrm{H}_{2} \mathrm{SO}_{4}$ followed by steam distillation with $\mathrm{NaOH}$ solution, with a $\mathrm{H}_{3} \mathrm{BO}_{3}$ solution as an indicator. After distillation, titration was performed with a standard $\mathrm{HCl}$ solution.

The physical characterization of the soil and substrates followed the methods described in Embrapa (1997). For the determination of the overall density, samples of the material were placed in a metallic ring of known volume, conducted to an oven with forced air circulation at 105 ㅇ. The overall density was then determined by dividing the weight of the kiln-dried sample and the volume of the metal ring.

The particle density was determined from the weight of 20 $\mathrm{g}$ of the kiln-dried material at 105 ㅇ, which was transferred to a $50 \mathrm{~mL}$ volumetric flask. The flask was filled with ethyl alcohol. The particle density was then calculated by subtracting the volume of the flask and the volume of alcohol spent, the result of which was divided by the weight of the kiln-dried sample. After obtaining the overall density and the density of particles, porosity was obtained by the relationship between both physical attributes, subtracted by 1 .

The piles were inserted vertically into the substrates, contained in polyethylene bags with dimensions of $0.12 \mathrm{x}$ $0.20 \mathrm{~m}$, with one node buried and the other above the substrate. Watering was carried out when necessary in order to maintain the moisture content of the substrates between 60 and $80 \%$ of the field capacity.

\section{Variables analyzed}

At 30 days after planting, the following variables were evaluated: cutting survival rate (S), based on a count of the live cuttings; leaf area (LA), using the photographic record of the leaf and subsequent digitalized image analysis with the aid of the Image $J^{\circledR}$ software; sprout length (SL), determined from the ground level to the top of the seedling with a millimeter ruler; sprout diameter (SD), measured with a digital caliper (Digimess ${ }^{\circledR}$ ); root length $(R L)$, measured with the aid of a ruler graduated in millimeters; root volume (RV), calculated in accordance with Basso (1999) by measuring the displacement of the water column in a graduated cylinder; aerial part dry mass (APDM) and root dry mass (RDM), determined by placing the plant material in a greenhouse with forced air circulation at a temperature of $65^{\circ} \mathrm{C}$ until constant weight was reached, which was measured on a scale with an accuracy of $0.01 \mathrm{~g}$.

\section{Statistical evaluation}

The data were submitted to the normality (Shapiro Wilk, $\mathrm{p}<$ 0.05 ) and homoscedasticity tests (Levane, $p<0.05$ ). When the assumptions were satisfied, an analysis of variance (ANOVA) was performed ("F" test) using the Infostat ${ }^{\circledR}$ software version 2020 (Di Rienzo et al., 2008). Subsequently, significant data were explored using regression analysis $(\mathrm{p}<$ 0.01 and $p<0.05)$. The average survival values of the cuttings were compared using the Tukey test $(p<0.05)$.

\section{Conclusion}

The use of babassu biomass as an organic fertilizer improves soil fertility and stimulates the growth and development of cassava seedlings in a sustainable production system. Babassu biomass is easy to acquire in the northeastern region of Brazil, making it a substrate of low economic value, which facilitates its use by family farmers. The recommended content of babassu biomass in the substrate during the initial development of cassava is $100 \%$.

\section{References}

Almeida BG, Donagemma GK, Ruiz HÁ, Braida JÁ, Viana JHM, Reichert JMM, Oliveira LB, Ceddia MB, Wadt PGS, Fernandes RBA, Passos RR, Dechen SCF, Klein VA, Teixeira WG (2012) Padronização de métodos para análise 
granulométrica no Brasil (Comunicado Técnico, 66). Rio de Janeiro: Embrapa. 11p.

Alves AAC (2002) Botânica e fisiologia da mandioca. In: Hillocks RJ, Thresh JM, Bellotti AC (ed) Mandioca: Biologia, Produção e Utilização, 1ạ edn. CABI Publishing. 67-89.

Amanullah MM, Vaiyapuri K, Sathyamoorthi K, Pazhanivelan S, Alagesan A (2007) Nutrient uptake, tuber yield of cassava (manihot esculenta crantz.) and soil fertility as influenced by organic manures. J Agron. 6(1): 183-187.

Biratu GK, Elias E, Ntawuruhunga P, Sileshi GW (2018) Cassava response to the integrated use of manure and NPK fertilizer in Zambia. Heliyon. 4(8): e00759.

Brasil. Instrução Normativa no 17, de 21 de maio de 2007. Aprova os Métodos Analíticos Oficiais para Análise de Substratos e Condicionadores de Solos. Diário Oficial da União, Brasília, 24 maio. 2007. Seção 1, 8 p.

Cruz JL, Pelacani CR, Araújo WL (2006) Effect of nitrate and ammonium on growth and efficiency of nitrogen use by cassava plants. Bragantia. 65(3): 467-575.

Embrapa (1997) Manual de métodos de análise de solos. 2a end. Embrapa: Rio de Janeiro. 212 p.

Fageria NK, Gheyi HR, Carvalho MCS, Moreira A (2016) Root growth, nutrient uptake and use efficiency by roots of tropical legume cover crops as influenced by phosphorus fertilization. J Plant Nutr. 39(6): 781-792.

Fernández NH, Anaya LA, Figueroa MS, Ancona, DB, Vázquez AO (2016) Impact of organic fertilization on physicochemical and functional properties of cassava starch. Starch-Starke. 68 (5-6): 549-557.

Gehring C, Zelarayán ML, Almeida RB, Moraes FHR (2011) Allometry of the babassu palm growing on a slash-andburn agroecosystem of the eastern periphery of Amazonia. Acta Amazon. 41(1): 127-134.

Gnahoua JBG, Ettien DJB, N'zué BONI, Ebah C, Kone B, Neve S, Boeckx P (2016) Intensification Pathway for Improvement of Smallholder Cassava Production Systems in Southern Côte D'Ivoire. Exp Agric. 53(1): 44-58.

Ibje (2019) Instituto Brasileiro de Geografia e Estatística. Levantamento sistemático da produção agrícola. Rio de Janeiro. Disponível em: http://www.ibge.gov.br/ (acesso em 20 abril 2020).

Kanai S, Adu-Gymfi J, Lei K, Ito J, Ohkura K, Moghaieb REA, El-Shemy H, Mohapatra R, Mohapatra PK, Saneoka H, Fujita K (2008) N-deficiency damps out circadian rhythmic changes of stem diameter dynamics in tomato plant. Plant Sci. 174(2): 183-191.

Kratz D, Nogueira AC, Wendling I, Souza PVD (2015) Substratos renováveis para produção de mudas de Mimosa scabrella. Floresta. 45(2): 393-408.

Macalou S, Musandu A, Mwonga S (2018) Cassava genotypes N P K nutrient uptake in leave and its growth and yield parameters regression under inorganic NPK (15-15-15) application rates in southern Mali, West African. Adv Agric Sci. 6(4): 42-51.

Munyahali W, Pyper P, Swenner R, Walangululu J, Vanlauwe B, Merckx R (2017) Responses of cassava growth and yiled to leaf harvesting frequency and NPK fertilizer in South
Kivu, Democratic Republico of Congo, Field Crops Res. 214: 194-201.

Muojiama SO, Agbo CU, Eze SC, Uba CU (2018) Agronomic evaluation of new varieties of cassava (Manihot esculenta Crantz) under different rates and modes of NPK (12-12-172) fertilizer application in two seasons. Not Sci Biol. 10(1): 107-116.

Namoi NL, Onwonga RN, Onyango CM, Karuku GN, Kathumo VM (2014) Assessment of soil nutrient balances in organic based cassava (Manihot esculenta Crantz) and sorghum (Sorghum bicolor (L.) Moench) cropping systems of Yatta Subcounty, Kenya. Am J Exp Agric. 4:1557-1578.

Omar NF, Hassan SA, Yusoff UK, Abdullah NAP, Wahab PEM, Sinniah UR (2012) Phenolics, flavonoids, antioxidant activity and cyanogenic glycosides of organic and mineralbase fertilized cassava tubers. Molecules. 17(3): 23782387.

Pereira GAM, Lemos VT, Santos JB, Ferreira EA, Silva DV, Oliveira MC, Menezes CWG (2012) Crescimento da mandioca e plantas daninhas em resposta à adubação fosfatada. Rev Ceres. 59(5): 716-722.

Rodrigues AR, Alves JMA, Uchôa SCP, Albuquerque JDAA, Rodrigues GS, Barros MM (2008) Avaliação da capacidade de enraizamento, em água, de brotações, ponteiros e estacas herbáceas de clones de mandioca de mesa. Rev Agro@m On-line. 2(1): 37-45.

Sangakkara UR, Wijesinghe DB (2014) Nitrogen Fertilizer Affects Growth, Yield, and N Recovery in Cassava (Manihot esculenta L. Crantz). Comum Sci Soil Plant Anal. 45(11): 1446 - 1452.

Santos HG, Jacomine PKT, Anjos LHC, Oliveira VA, Lumbreras JF, Coelho MR, Almeida JÁ, Cunha TJFE, Oliveira JB (2013) Sistema brasileiro de classificação de solos (Brazilian system of soil classification). 3. Rd edn. Rio de Janeiro, EMBRAPA. 353p.

Silva JR, Freire ES (1968) Efeito de doses crescentes de nitrogênio, fósforo e potássio sôbre a produção de mandioca em solos de baixa e alta fertilidade. Bragantia. 27(2) 357-364.

Sousa JTR, Moraes FHR, Geringh C (2016) Root biomass in a shifting cultivation system in the eastern periphery of Amazonia, and contribution of the babassu palm. Agrof Sys. 90: 351-360.

Sousa LB, Nóbrega RSA, Martins LV, Nóbrega JCA, LustosaFilho JF (2015) Cultivo de Sesbania virgata (Cav. Pers) em diferentes substratos. Revi Cienc Agrar. 58(3): 240- 247.

Taiz L, Eduardo Z, Moller IM, Murphy A (2014) Plant Physiology and Development, 6a edn. Artmed. $761 \mathrm{p}$.

Teixeira MA, Carvalho MG (2007) Regulatory mechanism for biomass renewable energy in Brazil, a case study of the Brazilian Babassu oil extraction industry. Energy. 32(6): 999-1005.

Turyagyenda LF, Kizito EB, Ferguson M, Baguma Y, Agaba M, Harvey JJW, Osiru DSO (2013) Physiological and molecular characterization of drought responses and identification of candidate tolerance genes in cassava. Aob Plants. 5: ptl007. 